\title{
The Hurricane Dilemma in the United States
}

\begin{abstract}
Tropical cyclones, known as hurricanes in the Atlantic and Eastern and Central North Pacific, typhoons in the Western North Pacific, and tropical cyclones elsewhere, are nature's most destructive phenomena. In the USA, hurricanes are categorized and damage is described according to the five categories of the Saffir-Simpson scale on the basis of wind velocity, storm surge, and property damage. Permanent populations of hurricane prone coastal communities are growing, and that coupled with increasing weekend, holiday, and seasonal populations puts large numbers of people at risk. It is increasingly difficult to evacuate these areas because highway development has not kept pace with the population increase. This serves as a strong impetus to develop accurate prediction and warning systems. The technology of modelling the interactions of wind, rain, and storm surge in relation to the topography and of comparing the models with the measured effects of actual hurricanes is improving the prediction and warning systems. However, the rate of forecast improvement continues to lag behind the need. The dilemma is to prevent the complacency caused by false alarms, yet still provide adequate warning times. (Ed.)
\end{abstract}

\section{Introduction}

Tropical cyclones are recognized as nature's most destructive phenomena owing to their frequency of occurrence and size. In the Atlantic, and Eastern and Central North Pacific, they are called hurricanes. In the Western North Pacific, they are called typhoons. Elsewhere they are called tropical cyclones. In 1970, the loss of life resulting from a single tropical cyclone striking Bangladesh has been estimated to exceed 500,000 people with some estimates of as many as 1 million dead.

Over the years, the loss of life from hurricanes devastating the United States has been enormous. In 1900, a hurricane struck Galveston, Texas, resulting in more than 6,000 deaths and the greatest natural disaster in the history of the United States. By comparison, the great San Francisco earthquake of 1906 resulted in just over 600 deaths. Other incidents of great loss of life from hurricanes occurred: in 1893 when there were nearly 2,000 deaths in the offshore islands near Charleston, South Carolina; in 1928 there were nearly the same number of deaths resulting from the hurricane that emptied Lake Okeechobee onto the surrounding communities of Florida; in 1926, a hurricane caused major damage in southeast

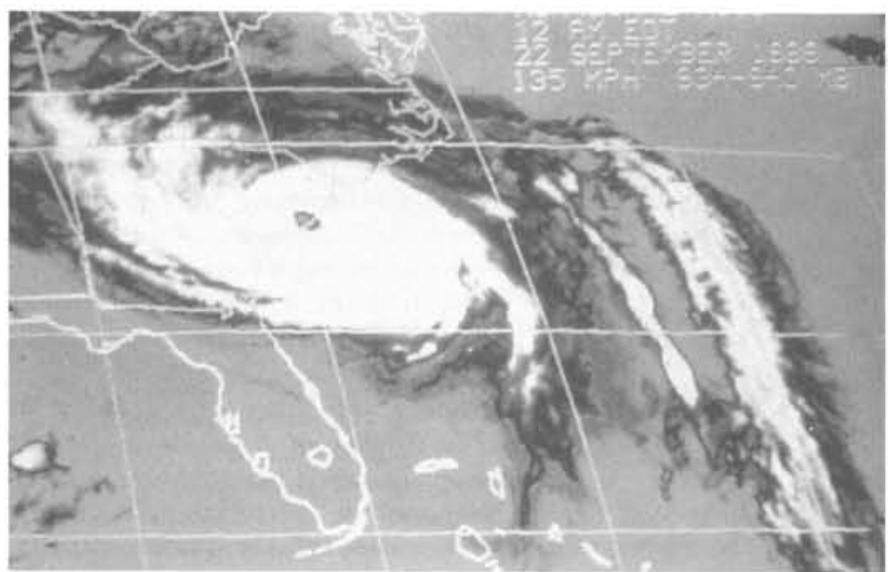

Figure 1.-Enhanced infrared satellite imagery of Hurricane Hugo with the "eye" over the coast near Charleston, South Carolina, USA. (This image in color on cover.)

Florida with estimates of the loss of life ranging between 250 and 500; in 1935, a hurricane striking the Florida keys killed more than 400 people; in 1938 the great New England hurricane resulted in more than 600 deaths; and in 1969 Hurricane Camille struck the Mississippi coast with winds estimated to be near $280 / \mathrm{km} / \mathrm{h}$ with gusts up to $320 \mathrm{~km} / \mathrm{h}$. Hurricane Camille produced a storm surge (dome of water accompanying the storm as it moved ashore) of $8 \mathrm{~m}$ above normal with waves on top of that. More than 250 people lost their lives as a result of Camille.

\section{Hurricane Hugo}

In 1989, Hurricane Hugo, one of the most powerful storms of the century, proved to be a double catastrophe for the United States. Its course through the Caribbean and Carolinas caused untold suffering and the largest economic loss from natural causes that the United States has ever experienced. The National Weather Service (NWS), through its National Hurricane Center( $\mathrm{NHC}$ ), reported that Hugo smashed into the South Carolina coast at Bulls Bay north of Charleston minutes before midnight on September 22, with winds estimated at $217 \mathrm{~km} / \mathrm{h}$. Four days earlier, the storm had crossed the U.S. Virgin Islands and Puerto Rico with equal force (figs. 1-3). During the hurricane's approach to the Leeward Islands, a National Oceanic and Atmospheric Administration (NOAA) research aircraft just to the east of Guadeloupe measured winds of $257 \mathrm{~km} / \mathrm{h}$ and a central pressure of 918 millibars. This qualified Hugo as a category-5 storm - the highest on the Saffir-Simpson scale (Herbert and Taylor, 1988), a scale that can be used to give an estimate of the potential property damage and flooding expected along the coast with a hurricane (table 1).

The storm was rated as a minimal category 4 when it pounded the Virgin Islands, Puerto Rico, and South Carolina. Although rainfall was moderate in the Caribbean and on the U.S. mainland, Hugo produced record storm tides of up to $6 \mathrm{~m}$ in South Carolina. 


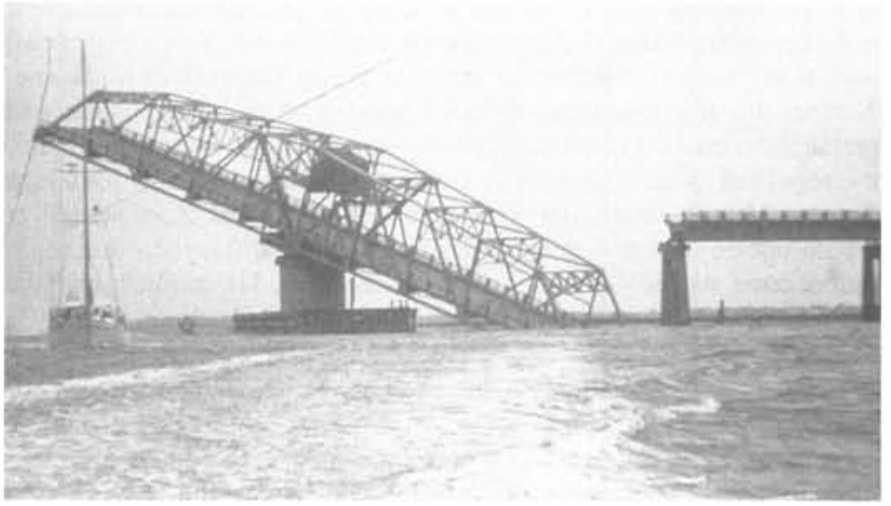

Figure 2.-Close up of damaged Ben Sawyer Bridge to Sullivan's Island after Hugo.

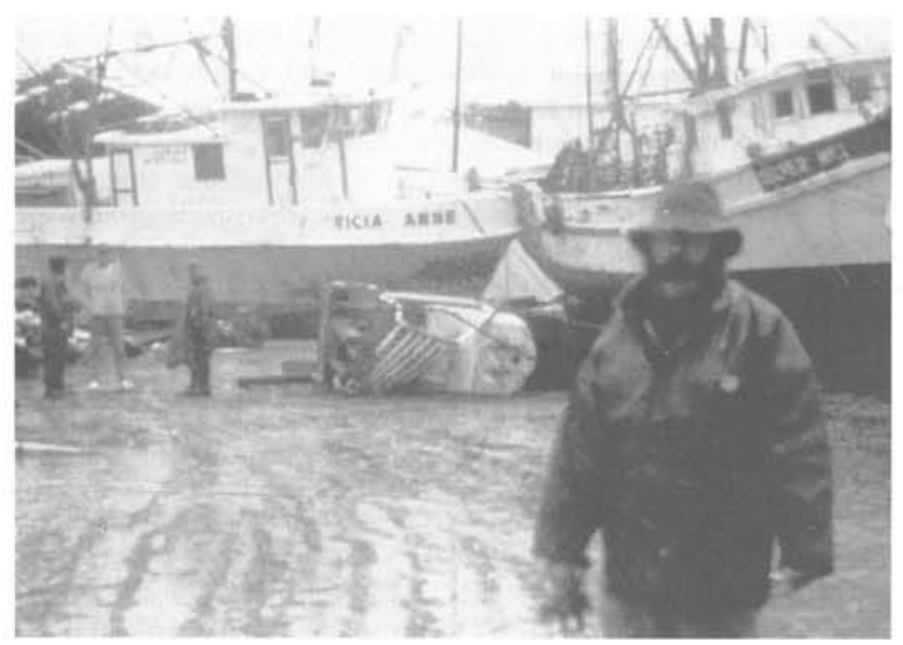

Figure 3.-Fishing fleet at McClellanville deposited on dry land. The person in the picture was the Captain of the Patricia Anne and stayed on the board during the hurricane. He stated that he sailed across a two story building at the height of the hurricane. Winds were probably near $209 \mathrm{~km} / \mathrm{h}$ here and the water rose about $5.2 \mathrm{~m}$ above sea level at this location.

Hurricane Hugo was the Nations costliest in terms of monetary losses but not in loss of life. Forty-nine directly related storm fatalities were recorded, 26 in the U.S. and its Caribbean Islands, and 23 others in the Leeward Islands. Damage estimates exceeded $\$ 9$ billion and economic losses occurred on the mainland, Puerto Rico, and the Virgin Islands. The mainland alone accounted for $\$ 7$ billion of the total damages (figs. 4-5).

Hugo's dangerous winds and storm surges had the potential of exacting a heavy death toll in the Carolinas and the Caribbean. Some 216,000 people evacuated from the coasts before the storm struck. The key to these evacuations, which undoubtedly saved hundreds of lives, was communications - well before Hugo made landfall, in the days immediately before the storm and during the event.

Excellent cooperation and coordination among NWS, State, county, and local officials has developed over the years. This cooperation provided the basis for a well-coordinated response to the hurricane. Working together, NWS and local officials had conducted ongoing weather awareness programs highlighting hurricane preparedness prior to the arrival of Hugo.

Hurricane Hugo was in many ways a success story with regard to the small number of lives lost. But, will we be as fortunate the next time a major hurricane threatens our coastlines? Better preparation will require improvements to forecast and warning systems as well as efforts to reduce the level of population and property at risk.

\section{The Hurricane Problem}

The permanent populations of the hurricane prone coastal counties of the United States continue to grow at a rapid rate (fig. 6). When weekend, seasonal, and holiday populations are added, the number of people on barrier islands such as Ocean City, Maryland, Gulf Shores, Alabama, Padre Island, Texas, and those off the South Carolina coast, increase by ten to 100 fold or more. Such areas are subject to inundation from the rapidly rising waters associated with hurricanes and known as the storm surge. Such inundation generally results in catastrophic damage and potentially large losses of life.

Over the past several years, the warning system has been adequate for providing time for the great majority of the people on barrier islands and along the immediately threatened coast to move inland away from the threat when hurricanes have struck. However, it is becoming more difficult each year to evacuate people from these areas because the roadway systems have not kept pace with the rapidly increasing population growth. This results in a requirement for longer and longer lead times for safe evacuation. Unfortunately, extended forecasts providing this lead time suffer from inherent uncertainty.

Table 1.-The Saffir-Simpson hurricane scale.

\begin{tabular}{ll}
\hline Category & Definition-Effects \\
\hline ONE & Winds 74-95 MPH (119-153 km/h) or storm surge 4-5 $\mathrm{ft}(1.2-1.5$ \\
$\mathrm{m})$ above normal. No real damage to building structures. Damage \\
primarily to unanchored mobile homes, shrubbery and trees. Also, \\
some coastal road flooding and minor pier damage.
\end{tabular}

TWO Winds $96-110 \mathrm{MPH}(154-178 \mathrm{~km} / \mathrm{h})$ or storm surge $6-8 \mathrm{ft}(1.8-2.4$ $\mathrm{m})$ above normal. Some roofing material, door and window damage to buildings. Considerable damage to vegetation, mobile homes and piers. Coastal and low-lying escape routes flood $2-4 \mathrm{~h}$ before arrival of center. Small craft in unprotected anchorages break moorings.

THREE Winds 111-130 MPH $(179-209 \mathrm{~km} / \mathrm{h})$ or storm surge 9-12 ft $(2.7-3.7 \mathrm{~m})$ above normal. Some structural damage to small residences and utility buildings with a minor amount of curtainwall failures. Mobile homes are destroyed. Flooding near the coast destroys smaller structures with larger structures damaged by floating debris. Terrain continuously lower than $1.5 \mathrm{~m}$ above sea level (ASL) may be flooded inland $13 \mathrm{~km}$ or more.

FOUR Winds 131-155 MPH $(210-250 \mathrm{~km} / \mathrm{h})$ or storm surge $13-18 \mathrm{ft}$ $(4-5.5 \mathrm{~m})$ above normal. More extensive curtainwall failures with some complete roof structure failure on small residences. Major erosion of beach areas. Major damage to lower floors of structures near the shore. Terrain continuously lower than $3 \mathrm{~m}$ ASL may be flooded requiring massive evacuation of residential areas inland as far as $9.6 \mathrm{~km}$.

FIVE Winds greater than $155 \mathrm{MPH}(250 \mathrm{~km} / \mathrm{h})$ or storm surge greater than $18 \mathrm{ft}(5.5 \mathrm{~m})$ above normal. Complete roof failure on many residences and industrial buildings. Some complete building failures with small utility buildings blown over or away. Major damage to lower floors of all structures located less than $4.5 \mathrm{~m} \mathrm{ASL}$ and within $450 \mathrm{~m}$ of the shoreline. Massive evacuation of residential areas on low ground within $8-16 \mathrm{~km}$ of the shoreline may be required. 
The combination of the risk factor for the growing populations in the barrier islands and other vulnerable locations and the uncertainties in the forecast presents major dilemmas for forecasters and local and State emergency management officials alike. The dilemma is how do you prevent complacency caused by "false alarms" and yet provide adequate warning times?

Adequate preparations for hurricanes are expensive. When a hurricane is forecast to move inland on a path perpendicular to the coast the area placed under warning is about $480 \mathrm{Km}$ in length for the average strength hurricane. The average cost to prepare for a hurricane is more than $\$ 50$ million for portions of the Gulf Coast. This is just the cost of boarding up homes, closing down businesses, evacuating oil rigs, and so forth, and does not include economic losses that result from disruption of commercial activities such as loss of sales and tourists canceling their reservations. In some coastal locations, the loss for a Labor Day weekend alone can be a substantial portion of the yearly income. If the width of the warned area has to be increased by 20 percent because of greater uncertainties in the

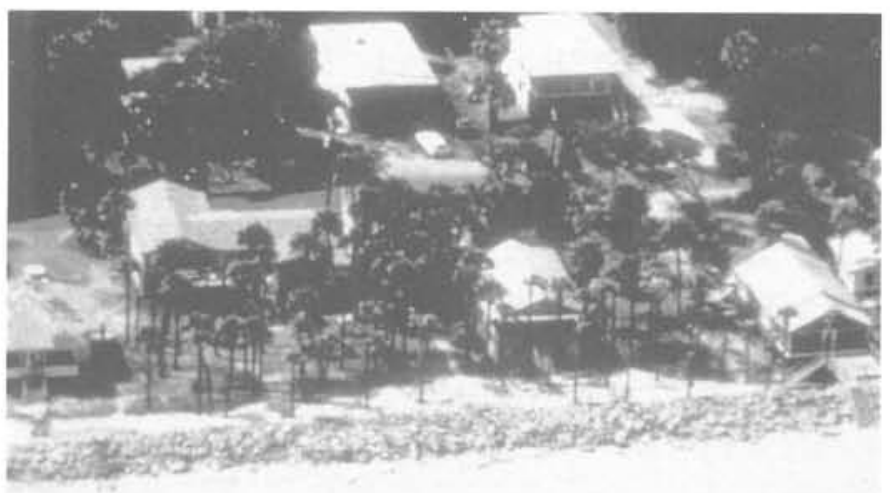

\section{-}

Figure 4.-Folly Beach homes before Hurricane Hugo. The beach has been eroding for many years and a typical means of trying to reduce the erosion has been the installment of hard barriers such as rip rap.

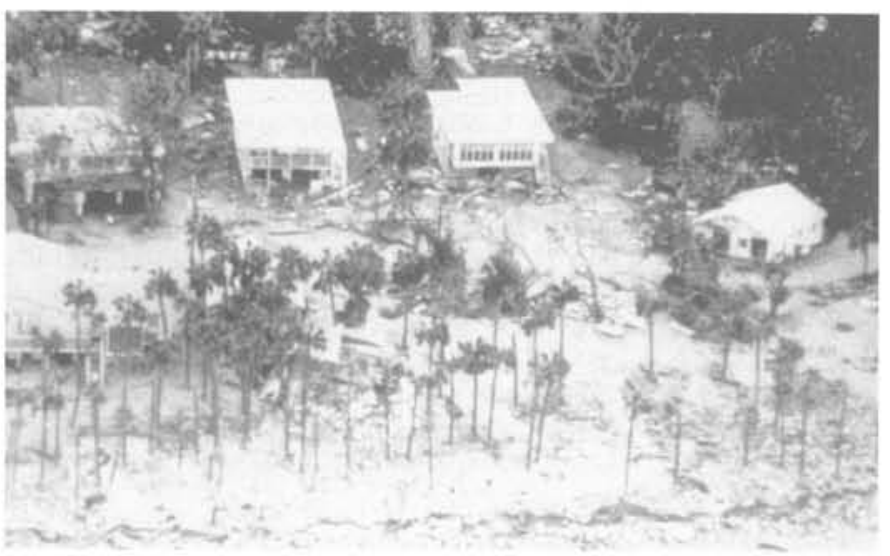

Figure 5.-Same area as 4 after Hurricane Hugo. Notice the barrier has been destroyed along with several houses behind it. The material that was behind the rock to hold the sand in place did not keep the barrier from collapsing under the pounding of the rising sea and wave action. forecast, the additional average cost of preparation for each event would be $\$ 10$ million. Uncertainties in the hurricane-strength forecast sometimes require warning for the next higher category of hurricane. This results in a large increase in the number of people evacuated and preparation costs. Of course, if these uncertainties meant that major metropolitan areas such as Galveston/Houston, New Orleans, Tampa, Miami, or a number of other major coastal cities would or would not be included in the warning area, the differences in preparation costs would be substantially more than $\$ 10$ million and the number of people evacuated could approach hundreds of thousands of people.

Of even greater concern to Federal, State, and local officials than the economic factor is the protection of life. But economic considerations are also a factor in the protection of life. People will not continually take expensive actions, which after the fact prove to have been unnecessary. If the population is consistently overwarned by wide margins, people may not respond the next time, which would result in large loss of life. To maintain credibility with the general population, Federal, State, and local officials cannot treat all hurricanes as if they were a Camille, Gilbert, or Hugo! Such an exaggerated approach may indeed provide maximum protection of life for a given event, but it endangers many more lives the next time, when the hurricane threat may even be greater.

Finally, the hurricane problem is compounded by the fact that a great majority of people who now live in the hurricane prone areas have never experienced a major hurricane (Saffir-Simpson scale category 3 or stronger) (Herbert and others, 1984). Hurricane Hugo was the first such storm to strike the east coast in almost $20 \mathrm{yr}$. Many coastal residents have been through weaker hurricanes or have been brushed by the fringe of a major hurricane. The result is a false impression of the damage potential of the hurricane. This frequently breeds complacency and delayed actions that could lead to a large loss of life. The massive media coverage of Hurricane Hugo and its destruction in the Caribbean and the Carolina coastal areas will hopefully provide some lessons learned for the citizens living along our coastlines.

Even with Hurricane Hugo still fresh in most peoples minds, three factors are still of major concern. First, major hurricanes are infrequent events for any single location. Second, major hurricanes striking the U.S. coast have been less frequent for the last two decades than for the three previous decades (see fig. 7). Finally, it has been during this period of low hurricane activity that the great majority of the present coastal residents have moved to the coast. The combination of these factors is illustrated in fig. 8, which shows that property damage has spiraled upward in tandem with the coastal populations until the last two decades when it leveled off. In fact, if it had not been for the more than $\$ 7$ billion loss caused by Hurricane Hugo in 1989, a significant decrease in losses would have been noted. Figure 9 shows the loss of life during this period and clearly demonstrates the improvement in the effectiveness of the hurricane forecast, warning, and response programs since the beginning of the century.

\section{Hurricane Forecast Improvement}

Many factors have contributed to forecast improvement, most related to advances in technology. The advent of meteorological satellites ranks as perhaps the greatest advance for hurricane forecasting. Hurricane reconnaissance from aircraft as well as refined data from ships, automated buoys, and radar have lead to a better understanding of the meteorological environment associated with tropical cyclones.

Geostationary satellites have made the largest contribution to hurricane forecasting. They provide constant surveillance of the at- 

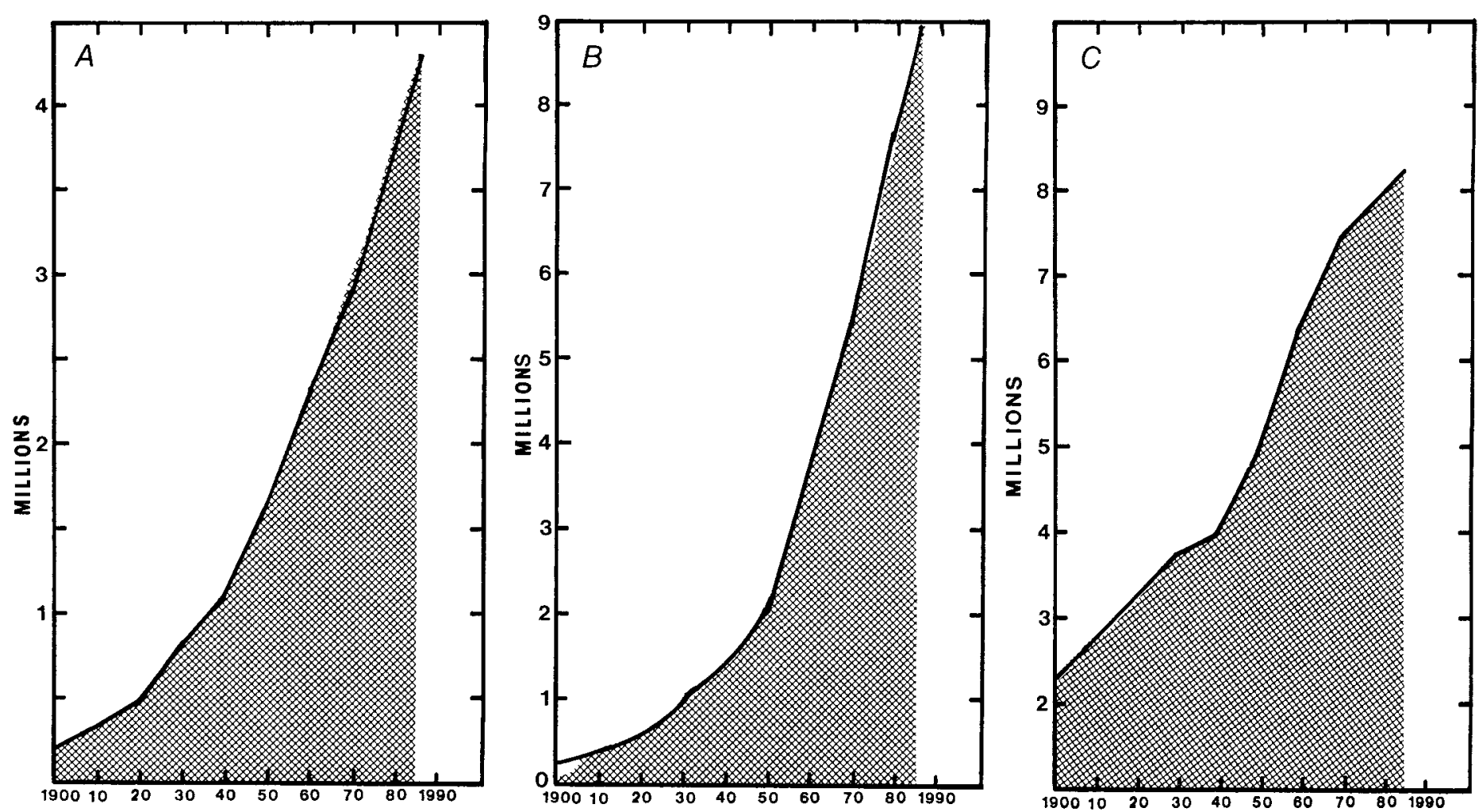

Figure 6. -Coastal County permanent population trends from 1900 to 1985 for (A) Texas, (B) Florida, and (C) Virginia, Maryland, Delaware, and New Jersey.

mosphere and allow the forecasters to track the development of tropical cyclones. The development of information processing techniques that use information from the satellites continues to be at the forefront of hurricane forecasting. The next generation of satellites is expected to include additional sophisticated sensing devices that may provide the next leap forward in hurricane forecasting.

Aircraft reconnaissance also plays a very important role in the improvement of hurricane forecasting (Markus and others, 1987). Reconnaissance flights give the forecaster invaluable details of the structure of the windfield in and around the hurricane. These data help determine the intensity of the storm and are put into the computer models that attempt to predict the track of the storms.

Hurricane forecasters readily use airborne radar from aboard the reconnaissance flights that fly into the storms. These data have provided extremely important information for researchers to develop computer simulations of the physical processes occurring within tropical cyclones. This research translates into a better understanding of hurricanes, and leads to improved forecasts of these storms. The advent of the Next Generation Weather Radar (NEXRAD) for the National Weather Service and other government agencies will provide further insight into the hurricane process, particularly as the storms approach land and move inland.

Normal observational data such as surface observations and atmospheric soundings are minimal over the oceanic regions. Reports from ships and from buoys can be important, but the data remain sparse.

Communication and data processing systems continue to improve with advances in technology. High-speed communications links enable immediate data transfer from such different sources as radar and aircraft reconnaissance to the processing centers. The data are then processed by computers that allow easy access by the hurricane forecaster. Fast communications systems are also responsible for rapid warning dissemination during critical events which helps generate the desired public response.

The National Weather Service's National Hurricane Center (NHC), located in Coral Gables. Florida, has responsibility for hurricane forecasting. Its mission is to provide tropical and subtropical meteorological and oceanographic products to governmental, private. and international users. These products consist of two groups. The first group is interactively derived meteorological and oceanographic analysis and associated aviation and marine forecasts. The second group includes tropical cyclone forecasts and warnings issued whenever a storm develops. These products are the primary information used in the decisionmaking process for action to protect potentially hundreds of thousands of lives for each major hurricane threat. In addition to its national responsibilities, the NHC is designated at Regional Specialized Meteorological Center (RSMC) under the auspices of the United Nations World Meteorological Organization. As an RSMC, the NHC supports the international community of the Caribbean, Northern South America, and Central America.

\section{The Tropical Cyclone Forecast and Warning Process}

\section{Before the Storm}

The tropical cyclone forecast and warning process begins well beforc the event appears on the horizon. The first step in the process is to 

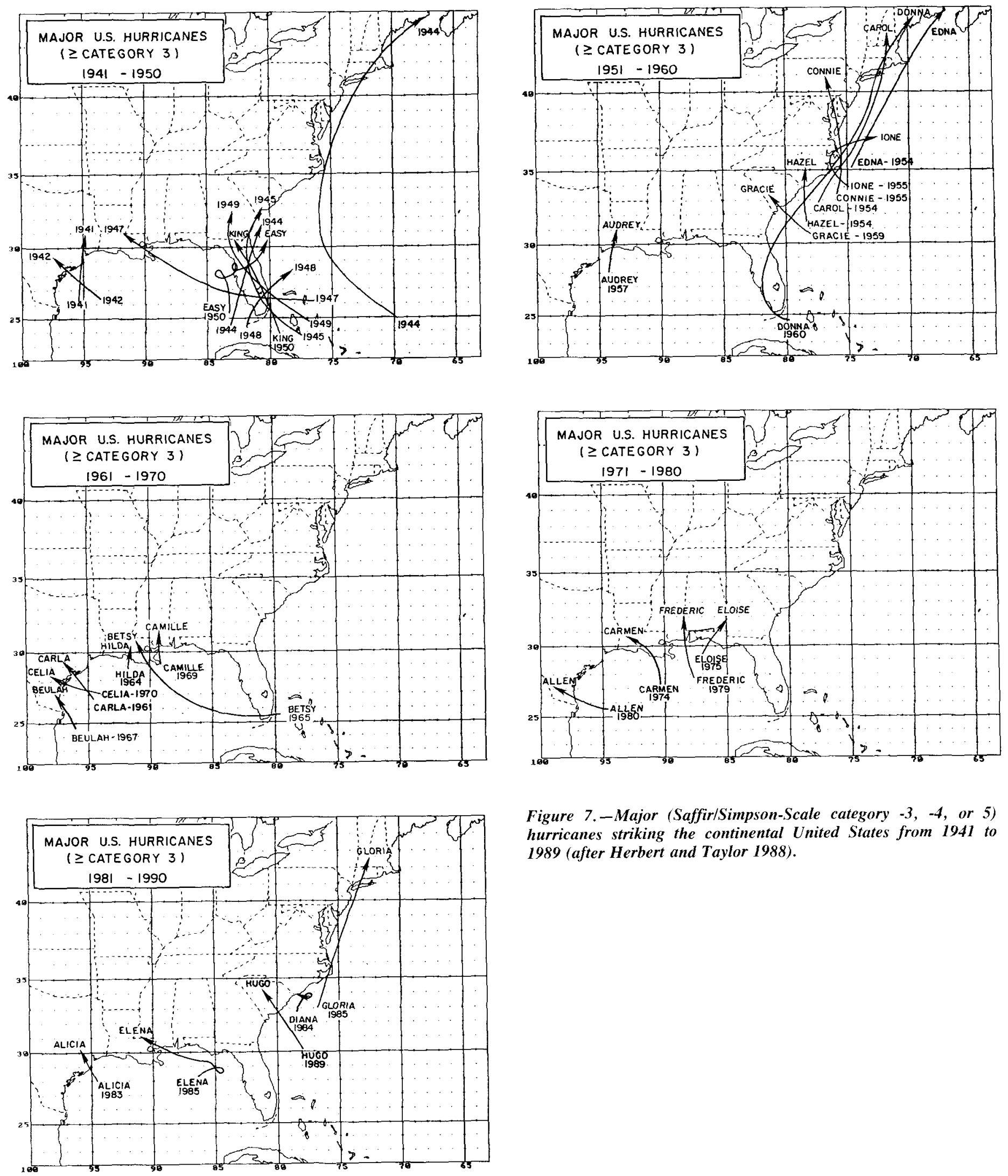

Figure 7. - Major (Saffir/Simpson-Scale category -3, -4, or 5) hurricanes striking the continental United States from 1941 to 1989 (after Herbert and Taylor 1988). 


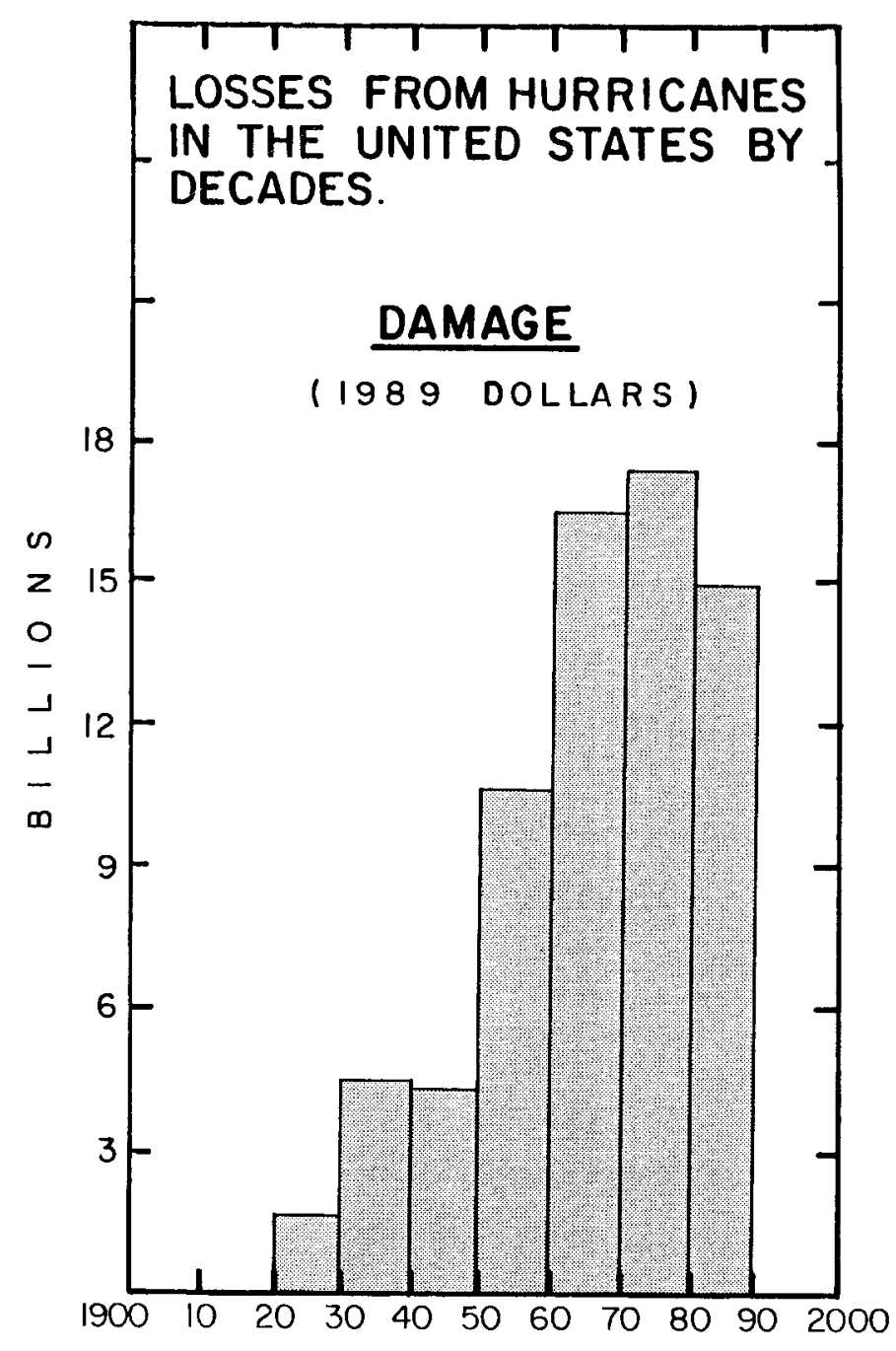

Figure 8.-Loss of property in the Continental United States due to hurricanes from 1915 through 1989 (modification and update of Gentry 1974).

determine the vulnerability of coastal locations. This is accomplished through the application of the Sea, Lake, Overland Surge from Hurricanes (SLOSH) model (Jarvinen and Lawrence, 1985).

\section{The SLOSH Model}

There are several steps involved in the application of the SLOSH model. The first is the basin development which is the application of the model to a particular basin. This is accomplished by entering bathymetry and topographic data into a model grid (fig. 10).

The next step involves tests of the model versus historical hurricane information. Each past hurricane affecting the area is carefully researched and reconstructed to determine its path, its wind and pressure field distribution, and the resulting water levels. The model is then run for each hurricane situation, and predictions of water rises or falls are compared with the historical values.

The next phase is an actual detailed reconnaissance of the basin to check actual land heights and barriers, to refine the information derived from topographic maps.

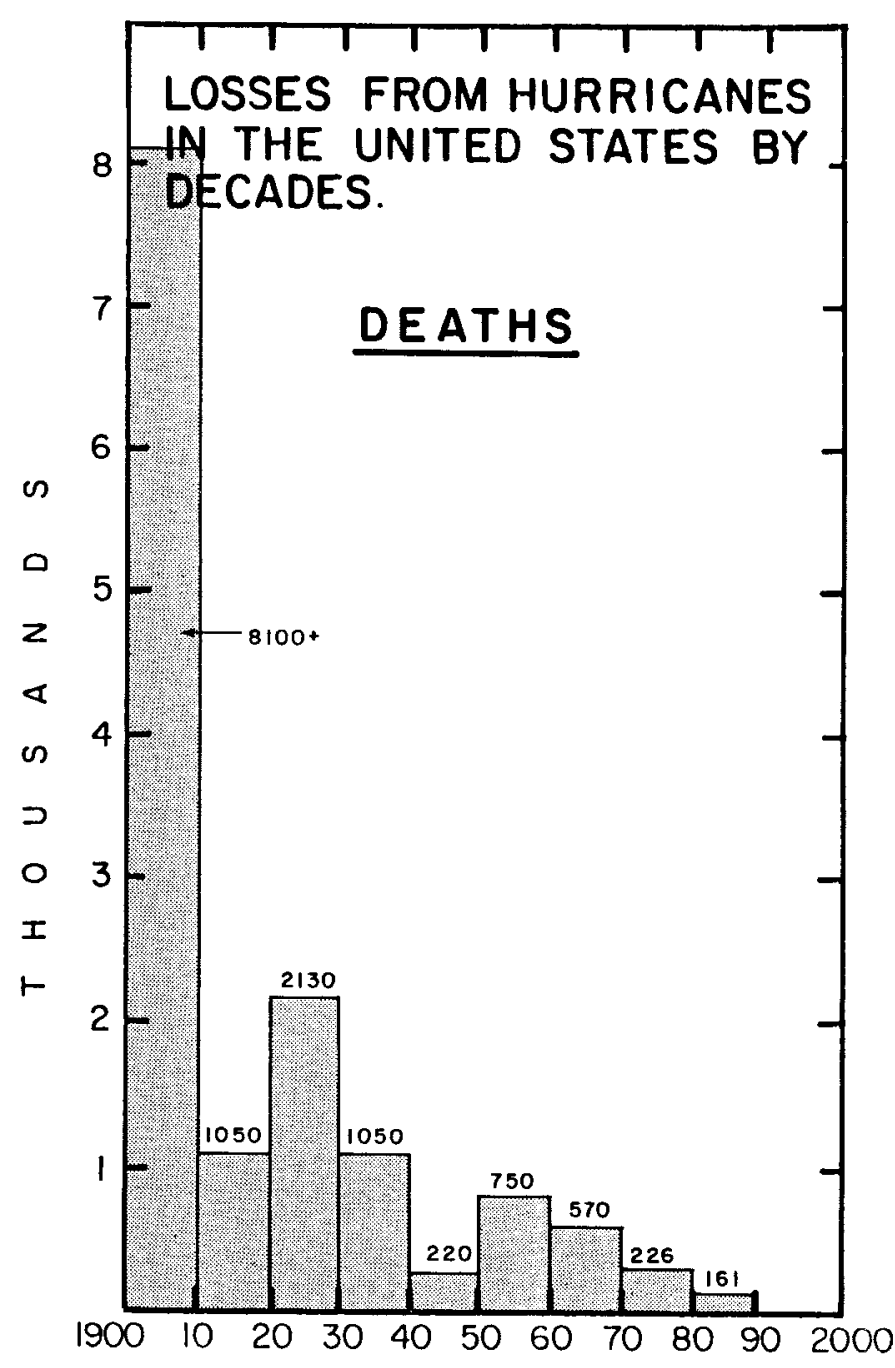

Figure 9.-Loss of life in the Continental United States due to hurricanes from 1900 through 1989 (modification and update of Gentry 1974).

After preparation and testing, the model is turned over to $\mathrm{NHC}$ for operational applications. NHC then simulates from 250 to more than 500 storms for each basin. The result is a collection of maps of maximum water level that depict areas covered by the potential storm surge for each storm scenario. Figure 11 is a map of the SLOSH forecast of storm inundation from Hurricane Hugo and the observed high water marks.

The next step is to complete evacuation studies on the basis of predicted areas of inundation. These evacuation studies include trans portation analyses, shelter analysis, and population behavior studies. The result of all of this is a definition of the problem along with required evacuation lead times for various hurricane scenarios. The availability of the SLOSH model was a major reason that over 216,000 people were successfully evacuated from the southeast U.S. coast in the path of Hurricane Hugo.

\section{Forecast Tools and Techniques}

Hurricane forecasting uses many of the same tools that are used in "normal" weather forecasting. These include satellite images, includ- 


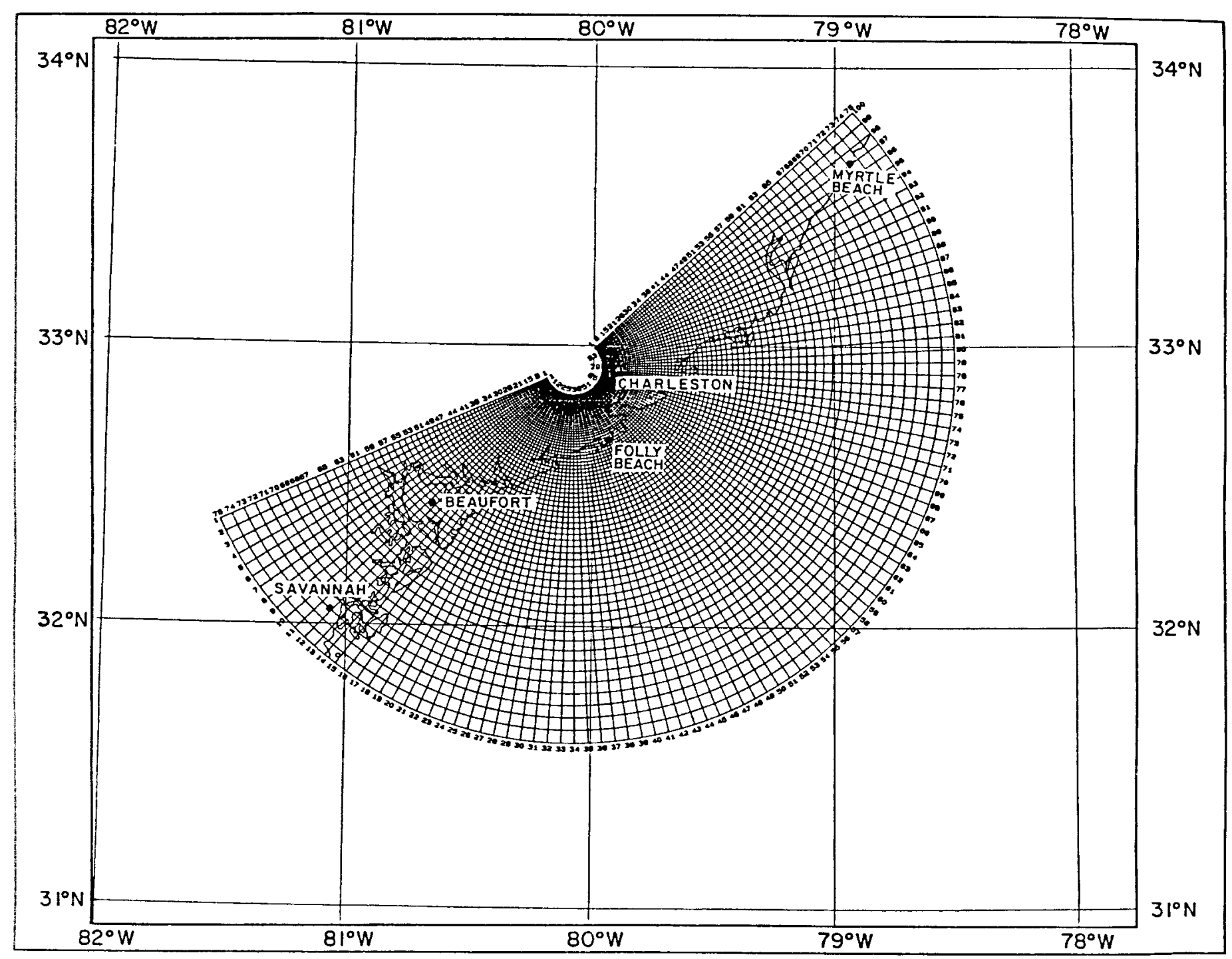

Figure 10.-80 $\times 100-$ point SLOSH modelling grid for the Charleston, South Carolina, basin.

Ing motion images, surface observations from both land and ships, analyses of the winds at different levels of the atmosphere. and computer simulations of the atmosphere. Owing to the sparsity of inventional data (surface observations and vertical sampling of the atmosphere (soundings)), hurricane forecasters place much more emphasis on satellite imagery and computer models of the atmosphere when determining their forecasts. Many different computer models have been developed to simulate tropical atmospheric conditions and is attempt to correctly forecast the track of the tropical cyclones. Infortunately, the same lack of data that inhibits the forecaster also degrades the computer forecast. Therefore, much of the hurricane forecasting process is based on the experience of the forecaster and lis interpretation of atmospheric conditions.

\section{The Warning Process}

The actual warning process involves a highly coordinated effort hetween NWS forecasters who are responsible for determining the expected meteorological and hydrological conditions and for issuance of the watches and warnings necessary to protect life and property; local, State, and Federal officials responsible for public action; and the media who help communicate the message to the public.

Many factors are involved when a hurricane watch or warning is issued. The primary focus for the warnings is to provide sufficient lead time to protect life and, to a lesser degree, property. Forecasters must be cautious not to overwarn an area in order to avoid the "cry-wolf" syndrome: if the public is under a warning and does not experience a hurricane, they will be less likely to take the necessary precautions the next time a storm threatens their area. For this reason, hurricane warnings are usually preceded by hurricane watches, and the warned area tends to be smaljer than the watch area as the prediction of the path of the storm becomes less uncertain.

The warning process involves close coordination and communication between the NHC, the local NWS forecast offices, and the affected State and local officials. These officials are given a briefing of the expected warning areas, the times of the warnings, and the expected meteorological conditions that will accompany the storm. 
The final and perhaps most important step in the warning process is the communication of the warning to the general public. This must be done so that the public will respond the way the emergency officials expect and in such a way as to preserve lives and property. The coordination of communications is most important so that the public receives no conflicting information. In this regard it is necessary for members of the media to work together and not try to be "one up" on their associates. If coordination fails, the public could receive conflicting information resulting in confusion and failure to react to the warnings in the proper manner. This may result in unnecessary loss of property and perhaps loss of life as well. Fortunately, in the US, the present communication system allows the public to receive the warning information directly from the NWS' NHC. The coordination of communications in this warning system is still not totally effective, but misinformation reaching the public has been greatly reduced.

\section{Future Hurricane Forecasting and Warning} Operations

Forecasters and computer models continue to suffer from a lack of meteorological observations over oceanic regions. There are plans for the next generation of satellites to provide more remote sensing capabilities and perhaps help fill the current data void. The outlook for hurricane forecasting is that best analysis of the atmosphere and forecast of tropical cyclones or hurricanes will come from people making qualitative interpretations of computer models.

The NWS is being equipped with a state-of-the-art nex:generation weather doppler radar systems (NEXRAD) that will add a new dimension to its hurricane warning capabilities. NEXRAD sy: tems will provide detailed information about the wind field accon:panying the tropical cyclone as it moves inland. This will permit

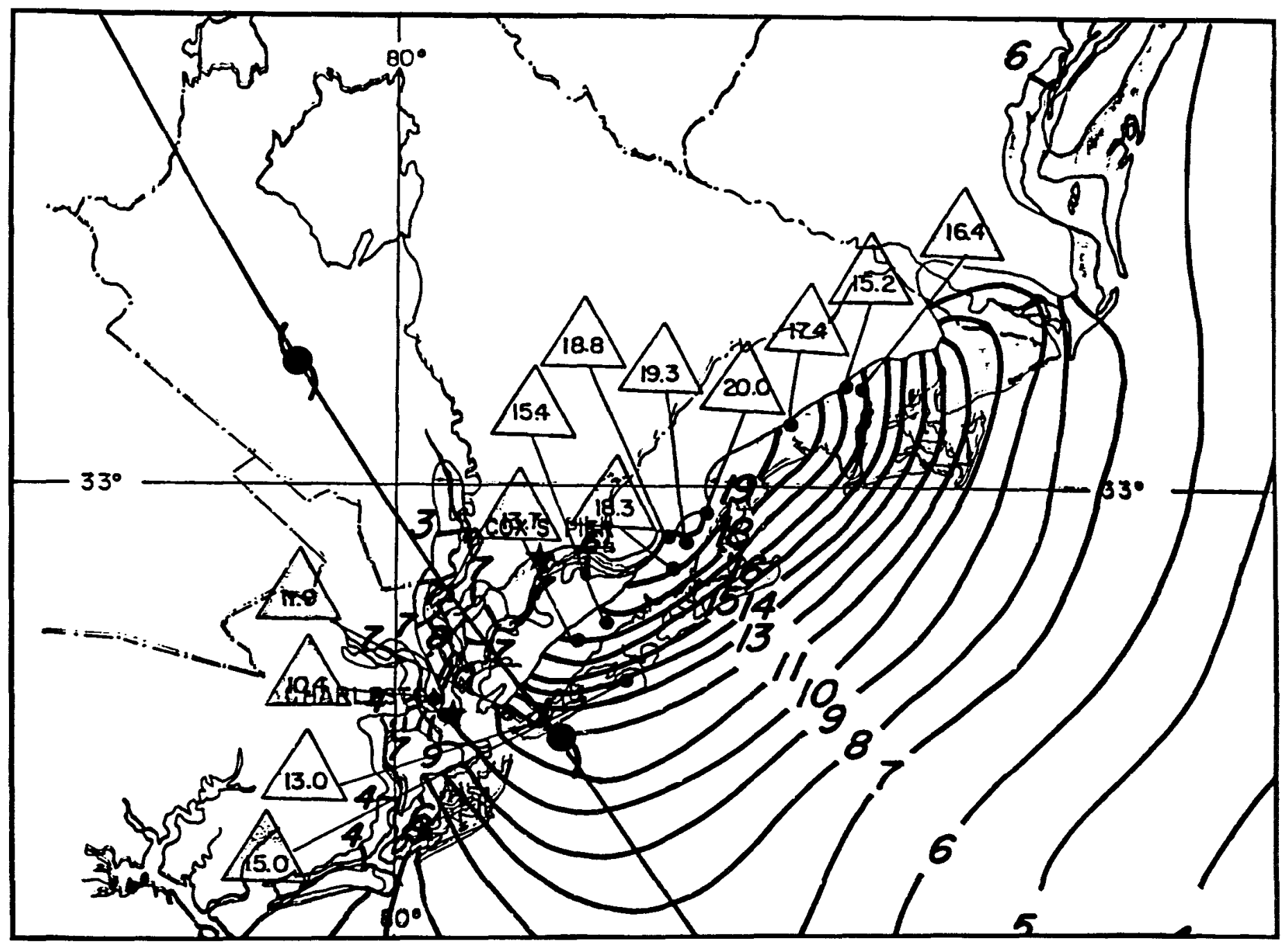

Figure 11.-Storm-surge estimates from the SLOSH model simulation of Hurricane Hugo, (contoured height values in feet and areas of inundation in dark green) and actual after-the-fact still-water height measurements in triangles. Note the good agreement between actual and predicted measurements. These types of comparisons have resulted in confidence in SLOSH simulations and these simulations are now the basis for most evacu. ation plans along the Gulf of Mexico and East Coasts of the U.S. 
more refined warnings during hurricane events. NEXRAD may also aid in the forecasting of rainfall amounts associated with tropical systems as they move inland.

The planned modernization of the NWS includes other features in addition to the implementation of the NEXRAD network. As part of this modernization, the National Meteorological Center in Suitland, Maryland. now employs a class VII computer on which the next generation of hurricane computer prediction models will run. The Advanced Weather Information and Processing System (AWIPS) of the NWS is an interactive computer system that is being developed for use throughout the NWS. This will be the primary tool for assimilation of all forecast and warning information available to the forecaster and will allow for rapid display and transmission of critical meteorological information.

The modernized weather service will provide more and improved detailed watch and warning information during a hurricane event. This should minimize confusion and miscommunication and allow for a more effective warning and evacuation process.

\section{Reducing People and Property at Risk}

While evacuation planning and other emergency measures have been the traditional approaches to mitigating the effects of hurricanes and other severe storms. the exponential growth in population in the Nation's coastal areas is requiring that new management efforts be undertaken to minimize the people and property vulnerable to these storms. These efforts include restrictions on the level of development and controls on the types of construction in vulnerable areas, and protection or enhancement of natural features that serve as buffers to the forces of coastal storms.

The first national efforts to deal with hurricane hazard mitigation were found in the passage of the National Flood Insurance Act in 1968. later modified and broadened with the passage of the Flood Disaster Assistance Act of 1973. This legislation established the National Flood Insurance Program that was intended to mitigate future damage and provide protection for property owners from flood-related damage. To be eligible for insurance, a community was required to undertake hazard-mitigation activities, that is, the adoption of floodplain management ordinances. The program also established minimum construction standards for buildings in vulnerable areas that are based on the level of risk from flooding - "flood proofing." In 1989, the liability under the Flood Insurance Program for only the coastal V-zones (areas subject to inundation by the 100 -year flood with additional hazards from wave action) was $\$ 5.2$ billion on the 64,000 policies in effect.

In 1972, Congress passed the Coastal Zone Management Act (CZMA) to encourage States to use a comprehensive approach to the resources and problems along the coast in order to manage their coastal areas better. Amendments to the Act in 1980 encouraged Federally approved State coastal management programs to manage coastal development in order to "minimize the loss of life and the destruction of property in flood-prone, storm-surge, geologically hazardous, and erosion-prone areas, and in areas likely to be affected by land subsidence and salt-water intrusion."

Since the passage of the CZMA. States with Federally approved coastal management programs have undertaken a number of activities to address the above goal. These have included funding hurricane evacuation plans, poststorm development and recovery plans, the development and implementation of setbacks to limit development in hazardous areas, and programs for the protection of beaches and dunes that serve to protect developed coastal property. This activity also includes the enactment of specifications or limitations on the construction of erosion-control structures that can interfere with natural shoreline processes.

When Hurricane Hugo struck in 1989. South Carolina was just beginning to implement its Beach Management Act. This Act established a development setback along the coast derived from expected beach erosion over 40 years, prohibited new erosion-control structures, required the development of beach management plans, and established limits on construction seaward of a baseline set at the crest of an ideal primary oceanfront dune. It is this type of management effort that coastal governing bodies need to undertake in order to reduce losses from future hurricanes.

\section{Possible Increase in Intense Landfalling Hurricanes in the Coming Decade.}

One concern of the future is that hurricane activity may return to the frequencies experienced during the 1940's through 1960's.

A recent analysis by Dr. William H. Gray (Gray, 1990) of Colorado State University, an expert on tropical cyclones, concluded that when rain in the Western Sahel region of Africa is plentiful, more strong hurricanes could develop in the Atlantic and strike the United States. The years from 1947 through 1969 constituted such a period when 13 hurricanes with winds of more than $177 \mathrm{~km} / \mathrm{h}$ struck the East Coast and Florida. Eleven of these hurricanes were Category 3, and Hurricanes Donna (1950) and Hazel (1954) were at the Category -4 level (see fig. 7). Gray has noted a strong correlation to the development of fewer strong hurricanes when there is a drought in the Western Sahel. That was the case from 1970) through 1987 when only one storm (Hurricane Gloria-1985) with peak winds of more than $177 \mathrm{~km} / \mathrm{h}$ struck the East Coast. It is believed that in "wet" years a slight warming in sea-surface temperature favors the development of stronger summer monsoons over West Africa. This, in turn, creates a more favorable environment for low pressure disturbances, or "waves," that originate over West Africa and evolve into hurricanes as they move into the Atlantic. These waves encounter an environment of low air pressure at the surface, warmer water, and wind patterns more favorable for strengthening.

At the same time, Dr. Gray believes that when prevailing easterly winds blowing over West Africa become weaker, this allows the tropical waves to move more slowly to the west, and they become bigger and better organized as observed in prehurricane cloud patterns. In dry Sahel years, the waves tend to be smaller and less well organized, move faster and dissipate more quickly as they move out over the ocean.

Given the multi-decadal cyclical nature of West African precipitation and the apparent recent breaking of the 18-year Sahel drought during 1988-89, and if Dr. Gray is right, it is possible that we will see a return to an increased incidence of intense hurricanes landfalling on the U.S. and Caribbean coasts during the 1990's and early years of the 21 st century (New York Times, 1990). Hurricanes Gilbert (1988) and Hugo (1989) may be but the forerunners of this increased intense hurricane activity.

\section{Conclusion}

Advancing technology is providing the opportunity to greatly increase the rate of improvement and to provide better warning products along the coast and inland. However, the rates of forecast improvement will continue to be much slower than the rate of population growth in hurricane-prone areas. Unless adequate means 
of evacuation and (or) places of refuge are provided for residents in existing and planed communities on barrier islands and other vulnerable coastal communities and unless there is a reduction in the growth in vulnerable areas, future hurricanes may produce a significant increase in loss of life and property.

According to Dr. Robert Sheets, Director of the National Hurricane Center, Hugo (for all the damage it did) struck the least vulnerable spot on the Atlantic Coast (the highest winds and tides struck the sparsely populated Marion National Forest). Had Hugo made landfall 20 miles further south the death toll and destruction would have been far greater. And, if Dr. Gray's premise is correct about an increase in intense hurricanes threatening the Caribbean and East Coast of the United States, we had better be prepared for the worst. This is our hurricane dilemma.

\section{Acknowledgments}

This paper was written in part by abstracting information from a paper written by Dr. Robert Sheets, Director of the National Hurricane Center which appeared in the American Meteorological Societies 1990 Weather and Forecasting, v. 5, no. 2, p. 185-232. (The list of references on pages 230-232 of Sheets' paper provides an excellent bibliography for background reading on hurricane forecasting.) Other contributors included Marcella Jansen of NOAA's Office of Ocean and Coastal Resource Management and John Sokich of NOAA's National Weather Service's Office of Meteorology.

\section{References}

Gray, W.M., 1990, Likely increase in intense landfalling hurricanes in the coming decade: National Hurricane Conference, 33 p.

Herbert, P.J., and Taylor, G., 1988. The deadliest, costliest and most intense United States hurricanes of this century: Washington, D.C.,
National Oceanic and Atmospheric Administration Technical Memorandum NWS NHC-18.

Herbert, P.J., Taylor, G., and Case, R.A., 1984, Hurricane experience levels of coastal county populations-Texas to Maine: Washington, D.C., National Oceanic and Atmospheric Administration Technical Memorandum NWS NHC- 24 .

Jarvinen, B.J., and Lawrence, M.B., 1985, An evaluation of the SLOSH storm surge model: Bulletin American Meteorology Society, v. 66, p. $1408-1411$.

Markus, R.M., Halbeisen, N.F., and Fuller, J.F., 1987, Air Weather Service; our heritage, 1937-1987, Military Airlift Command, U.S. Air Force, Scott AFB, Illinois, $167 \mathrm{p}$.

New York Times, 1990, More strong hurricanes predicted for east in next 2 decades, 25 September 1990.

Sheets, R.C., 1990, The National Hurricane Center-Past, Present and Future, Weather and Forecasting, p. 185-232.

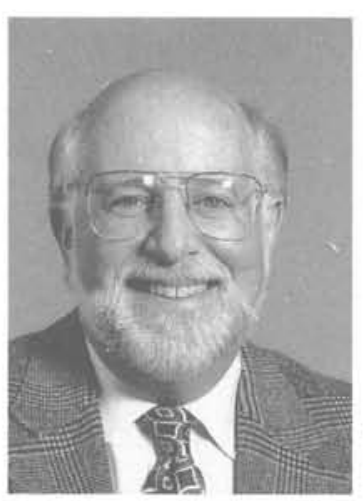

Edward Gross is the Chief of the $\mathrm{Na}$ tional Oceanic and Atmospheric Administration's (NOAA's) Atmospheric Services Branch. He is a graduate of the City College of New York and New York University, receiving his bachelor's and master's, respectively, in Meteorology. $\mathrm{He}$ has worked for NOAA for over 29 years. primarily with the National Weather Service in a variety of program areas in the Office of Meteorology and in NOAA's Office of Legislative Affairs the past 5 years. For the last two years, he has been the NOAA representative on the Subcommittee for Natural Disaster Reduction helping to establish the framework for the U.S. program addressing natural disaster reduction across Federal agencies. 